\title{
Measuring the New Governance Pillar of Agrarian Sustainability at Farm, Sectoral and National Level in Bulgaria
}

\section{Hrabrin Bachev}

Institute of Agricultural Economics, Sofia, Bulgaria. Email:hbachev@yahoo.com Tel: (359)884187358

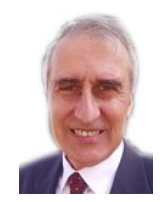

\begin{abstract}
In Bulgaria, like in many other countries, practically there are no comprehensive assessments of the governance sustainability of agriculture and its importance for the overall agrarian development. This study tries to fill the gap and suggests a holistic framework for understanding and assessing the governance sustainability of Bulgarian agriculture. The newly elaborated approach is "tested" in a large-scale study for assessing the governance sustainability of country's agriculture at national, sectoral, and farm levels. The study has proved that it is important to include the "missing" Governance Pillar in the assessment of the Integral sustainability of agriculture and sustainability of agro-systems of various types. Multiple Principles, Criteria and Indicators assessment of the Governance sustainability of Bulgarian agriculture indicates that the Overall Governance Sustainability is at a "Good" but very close to the "Satisfactory" level. Besides, there is a considerable differentiation in the level of Integral Governance sustainability of different agro-systems in the country. What is more, the individual indicators with the highest and lowest sustainability values determine the "critical" factors enhancing and deterring the particular and integral Governance sustainability of evaluated agro-system. Last but not least important, results on the integral agrarian sustainability assessment based on micro (farm) and macro (statistical, etc.) data show some discrepancies which have to be taken into consideration in the analysis and interpretation, while assessment indicators, methods and data sources further improved.
\end{abstract}

Keywords: Governance sustainability, Assessment, Agriculture, Subsectors, Agro-regions, Agro-ecosystems, Farming organizations, Bulgaria.

JEL Classification: Q12, Q18, Q56.

\section{Introduction}

A common feature of all suggested and practically used modern systems for assessing sustainability of agrosystems is incorporation of three "dimensions" or "pillars" of sustainability - economic, social and environmental (Bachev, Ivanov, Toteva, \& Sokolova, 2017; Cruz, Mena, \& Rodríguez-Estévez, 2018; EC, 2001; FAO, 2013; Hayati, Ranjbar, \& Karami, 2010; Kamali, Borges, Meuwissen, De Boer, \& Lansink, 2017; López-Ridaura, Masera, \& Astier, 2002; Lowrance, Hendrix, \& Odum, 2015; OECD, 2001; Sauvenier et al., 2005; Singh, Murty, Gupta, \& Dikshit, 2009; Terziev, Radeva, \& Kazakova, 2018; VanLoon, Patil, \& Hugar, 2005). In the last years a special attention has been increasing put on the (good) "governance" as a key for achieving multiple goals of sustainable development at corporate, sectoral, national and international levels (Bachev, 2010; Bosselmann, Engel, \& Taylor, 2008; EU, 2019; Gibson, 2006; Kayizari, 2018; Simberova, Kocmanova, \& Nemecek, 2012; UN, 2015). What is more, the list of sustainability objectives has been constantly enlarged encompassing numerous governance, cultural, ethical etc. standards and goals (Bachev, 2010; Scobie \& Young, 2018). Simultaneously "new" (cultural, human, governance, etc.) pillars has been widely added to the modern definition of sustainability and the systems of its evaluation and management (Altinay, 2012; ASA, 2019; Bachev, 2018; Nurse, 2006; RMIT University, 2017; UCLG, 2014).

The need to include "the fourth" governance pillar in the concept for understanding and the system of measurement of sustainability is increasingly justified in academic literature (Bachev, 2018; Bachev, 2010; Baeker, 2014; Fraser, Dougill, Mabee, Reed, \& McAlpine, 2006; Monkelbaan, 2017) as well as finds place in the official documents of different (government, international, private, etc.) organizations (City of Brooks, 2019; EU, 2019; IFAD, 1999). Accordingly, numerous indicators are proposed to evaluate the governance aspect of sustainability mostly at national and international level including the state of formal institutional framework, implementing policies and strategies, human resources development, established capacity, management of public authorities, stakeholder involvement in public decision-making and control, etc. (Bell \& Morse, 2008; Bhuta \& Umbach, 2014; CoastalWiki, 2019; Ganev, Popova, \& Bönke, 2018; Monkelbaan, 2017; Spangenberg, Pfahl, \& Deller, 2002). Nevertheless, the building of the system for understating and assessing the "new" governance aspect (pillar) of agrarian sustainability is a "work in progress". 
In Bulgaria, like in many other countries, there are a very few studies on governance issues related to agrarian sustainability (Bachev, 2018; Bachev, Ivanov, Toteva, \& Sokolova, 2016; Bachev \& Terziev, 2018; Bachev, 2010; Georgiev, 2013; Marinov, 2019; Sarov, 2019) and the governance aspect (pillar) of agrarian sustainability (Bachev, 2016; Bachev, Ivanov, \& Sarov, 2020; Bachev \& Terziev, 2017; Bachev \& Terziev, 2019; Bachev, 2018; Bachev, 2017). Moreover, practically there are no comprehensive assessments of the governance sustainability in the sector and its importance for the overall agrarian sustainability at present stage of development.

This paper tries to fill the gap and suggests a holistic framework for assessing the governance sustainability of Bulgarian agriculture. The newly elaborated approach is applied (tested) in a first in kind large-scale study for assessing the governance sustainability of country's agriculture at national, sectoral, and farm levels.

\section{Study Method and Data}

Sustainability of agriculture is a "system characteristic" and has to be perceived as "ability to continue over time" (Bachev, 2005; Hansen, 1996). It characterizes the ability (internal capability and adaptability) of agriculture to maintain its managerial, economic, social and environmental functions in a long period of time. Agrarian sustainability has four major aspects ("pillars") which are equally important and have to be always accounted for governance sustainability, economic sustainability, social sustainability, and environmental sustainability.

The "governance sustainability" characterizes the efficiency of the specific system of governance in an evaluated agro-system (national, subsector, ecosystem, regional, farming enterprise, etc.). Accordingly, a "good governance" means a superior governance sustainability, while a "bad" (inefficient) governance corresponds to inferior governance sustainability.

Maintaining multiple functions (sustainability) of agriculture requires an effective social order - a system of diverse (governing) mechanisms and forms regulating, coordinating, stimulating, and controlling the behavior, actions and relations of individual agents at various levels - farm, local, regional, national, transnational, global (Bachev, 2010). The system of governance includes a number of district components all of which have to be included in the sustainability assessment - institutional environment ("rule of the game'), market modes and mechanisms ('market order'), private modes and mechanisms ("private order'), and public modes and mechanisms (“public order’) Figure 1.

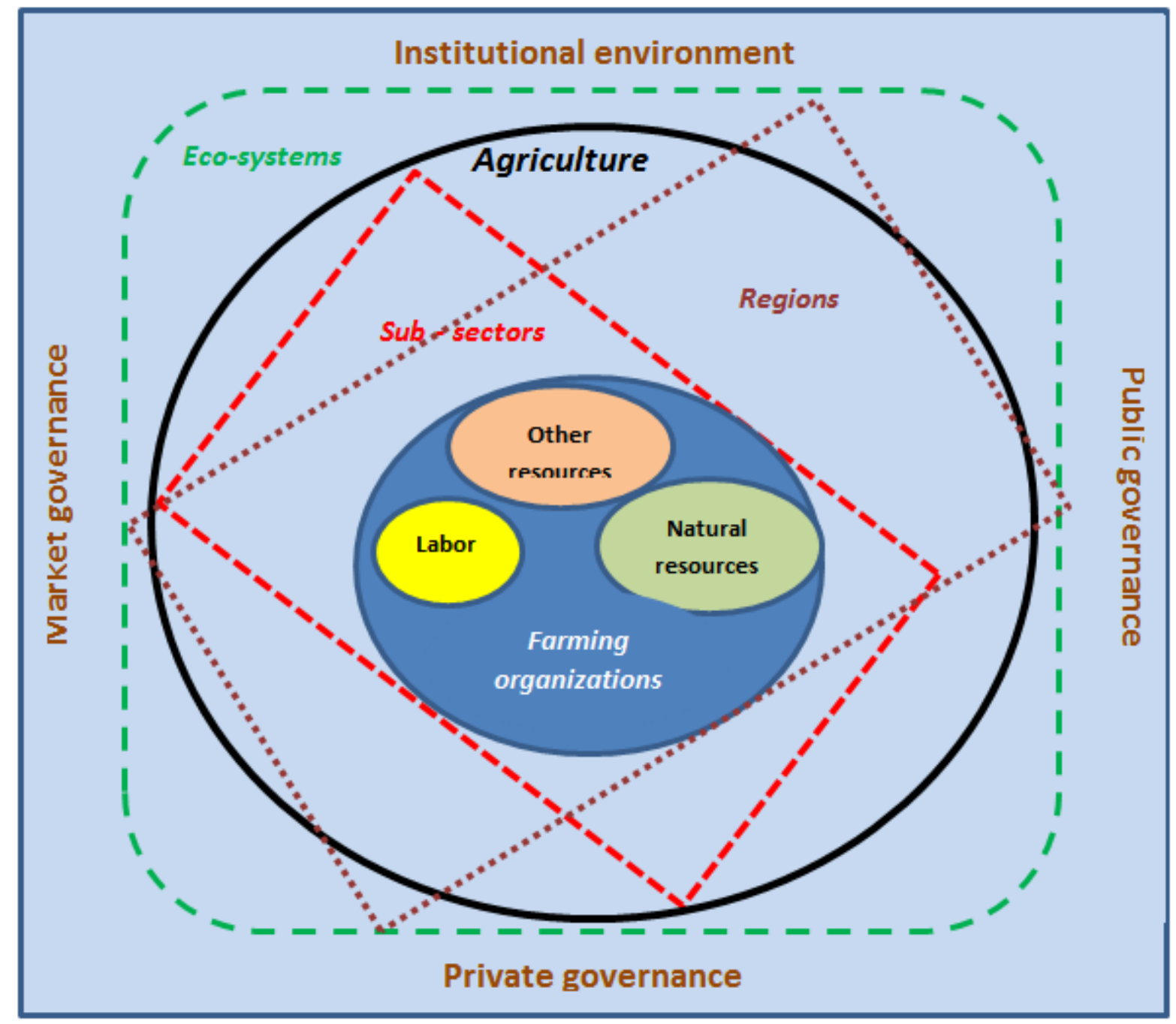

Figure-1. Components and levels of assessment of governance sustainability in agriculture.

In order to identify the individual indicators for assessing the (governance) sustainability of Bulgarian agriculture a hierarchical system of well-determined Principles, Criteria, Indicators, and Reference Values for each Aspect (Pillar) of sustainability is elaborated. Detailed justification of that new approach, and the ways and criteria for selection of sustainability Principles, Criteria, Indicators and Reference Values are presented in other publications by Bachev (2017); Bachev (2018) and Bachev et al. (2017); (Bachev et al., 2020).

The Governance Sustainability Principles are "universal" and relate to the multiple functions of the agriculture representing the states of the sustainability, which is to be achieved Figure 2. For the "specific" contemporary conditions of Bulgarian (and European Union) agriculture following five (governance sustainability) principles 
related to the generic (five) mechanisms and modes of governance ${ }^{1}$ are identified: "Good legislative system", "Democratic management", "Working agrarian administration", "Working market environment", and "Good private practices".

The Governance Sustainability Criteria are precise standards ("measurement approaches") for each of the Principle representing a resulting state of the evaluated system when the relevant sustainability Principle is realized. For the contemporary conditions of the Bulgarian agriculture 20 Criteria for assessing diverse aspects of the governance sustainability are specified. For instance, for the Principle "Good legislative system" four Criteria are selected: "Harmonization with the European Union policies", "Extent of the European Union policies implementation", "Beneficiaries' satisfaction of the European Union policies", and "Policies effects".

The Governance Sustainability Indicators are quantitative and qualitative variables of different types which can be assessed in the specific conditions of the evaluated agri-system allowing measurement of compliance with a particular Criterion. The set of Indicators provides a representative picture for the agrarian sustainability in all its aspects. For assessing the Governance sustainability of the Bulgarian agriculture at micro (farm) and macro (sectoral, regional, eco-system, etc.) levels a system of respectively 22 and 26 Indicators are specified ${ }^{2}$. For instance, for the Criteria "Policies effects" an Indicator "Level of subsidies comparing to the average for the sector" is selected for farm level, as well as two Indicators for the aggregate (sectoral) level - "Coefficient of subsidies distribution from Pillar 1" and "Coefficient of distribution of investment support comparing to share in Net Value Added".

For assessing the particular sustainability level a system of specific Reference Values (sustainability norms, range, and standards) for each Indicator is needed. The Governance Sustainability Reference Values are the desirable levels for each Indicator according to the specific conditions of the evaluated agro-system. They assist the assessment of the sustainability levels giving guidance for achieving (maintaining, improving) particular aspect and the overall agrarian sustainability. Most of the Reference Values show the level(s), at which the long-term sustainability of agrarian Governance sustainability is "guaranteed" and improved. Depending on the extent of the Reference value achievement the evaluated agro-system may be with a "high", "good", or "low" sustainability, or to be "unsustainable". For instance, agrarian system with a higher than the sectoral public support (level of subsidies) is more sustainable then others as far as "Policy effects" are concerned, and vice versa.

Very often individual Indicators for each Criterion and/or different Criteria, and Principles of sustainability are with unequal, and frequently with controversial levels. That significantly hardens the overall assessment requiring a transformation into "unitless" Sustainability Index and integration of estimates. Diverse quantitative and qualitative levels for each indicator are transformed into a Index of sustainability (ISi) applying appropriate scale for each Indicator (Bachev et al., 2018).

The Integral Sustainability Index for a particular Criterion $(\mathrm{SI}(\mathrm{c}))$, Principle $(\mathrm{SI}(\mathrm{p}))$, and Aspect of sustainability (SI(a)), and the Integral Sustainability Index (SI(o)) for evaluated agro-system is calculated applying "equal weight" for each Indicator in a particular criterion, of each Criterion in a particular Principle, and each Principle in every Aspect of sustainability. Using "equal" rather than differentiated weight is determined by the fact that individual Sustainability Aspects, and indeed Sustainability Principles, are "by definition" equally important for the Integral Agrarian Sustainability. At the same time, differentiation of the weights of individual Criteria within each Principle and the individual Indicators within each Criteria is difficult to justify as well as to a great extent unnecessary (practically unimportant for the Integral assessment) having in mind the big number and small relative contribution of each Indicator ${ }^{3}$.

The Integral Index for a particular Criterion (SI(c)), Principle (SI(p)), and Aspect of sustainability (SI(a)), and the Integral Sustainability Index $(\mathrm{SI}(\mathrm{o}))$ are arithmetic averages of the Indices of composite Indicators, Criteria and Principles. For assessing the level of Governance and Integral sustainability of agro-systems in Bulgaria the following scale, defined by the leading experts in the area (Bachev et al., 2018) are used: Index range 0,81-1 for a "High" level of sustainability; Index range 0.50-0,8 for a "Good" level of sustainability; Index range 0,26-0,49 for a "Satisfactory" level of sustainability; Index range 0,06-0,25 for an "Unsatisfactory" level of sustainability; Index range 0-0,05 for "Non-sustainable" state.

Elaborated holistic framework for assessing the Governance sustainability of Bulgarian agriculture is tested using experts and stakeholders assessments, and 2018 survey data from the managers of 104 "typical farms" of different size and juridical type, production specialization, and ecological and geographical locations. The structure of surveyed farms approximately corresponds to the real structure of farms in different categories in Bulgaria. Classification of the surveyed farms into juridical type, size, production specialization, and ecological and geographical location is done according to the official definitions currently used in Bulgaria (and European Union).

In Bulgaria, like in many other countries, there are no official data for calculating most of the governance, socio-economic and environmental sustainability indicators at lower (farm, eco-system, subsector, regional, etc.) level (Bachev et al., 2018). Therefore, micro and middle level assessment of socio-economic, environmental and governance sustainability is entirely based on the "original" first-hand information collected from the farm managers. The composite (Aspect and Integral) Sustainability Index of each evaluated agri-system (farming organization, agricultural subsector, agri-ecosystem, geographical region, etc.) is calculated as an arithmetic average of the Indices of relevant farms belonging to that system.

\section{Results and Discussion}

A multiple indicators assessment of the Governance sustainability level of Bulgarian agriculture indicates that the Index of Overall Sustainability is 0,51 - this represents a close to the lower ("Satisfactory") but still a "Good" level of Governance sustainability of the sector Figure 2.

${ }^{1}$ Components of the governance system of agriculture is comprehensively presented by Bachev. (2010).

${ }^{2}$ For the selection of the Sustainability Indicators a number of criteria, broadly applied in the sustainability assessment literature and practices, were used: "Relevance to reflecting aspects of sustainability", "Discriminatory power in time and space", "Analytical soundness", "Intelligibility and synonymity", "Measurability", "Governance and policy relevance", and "Practical applicability" (Sauvenier et al., 2005).

${ }^{3}$ Calculations with and without differentiated weights do not find any significant variations in the sustainability levels (Bachev et al., 2019). 


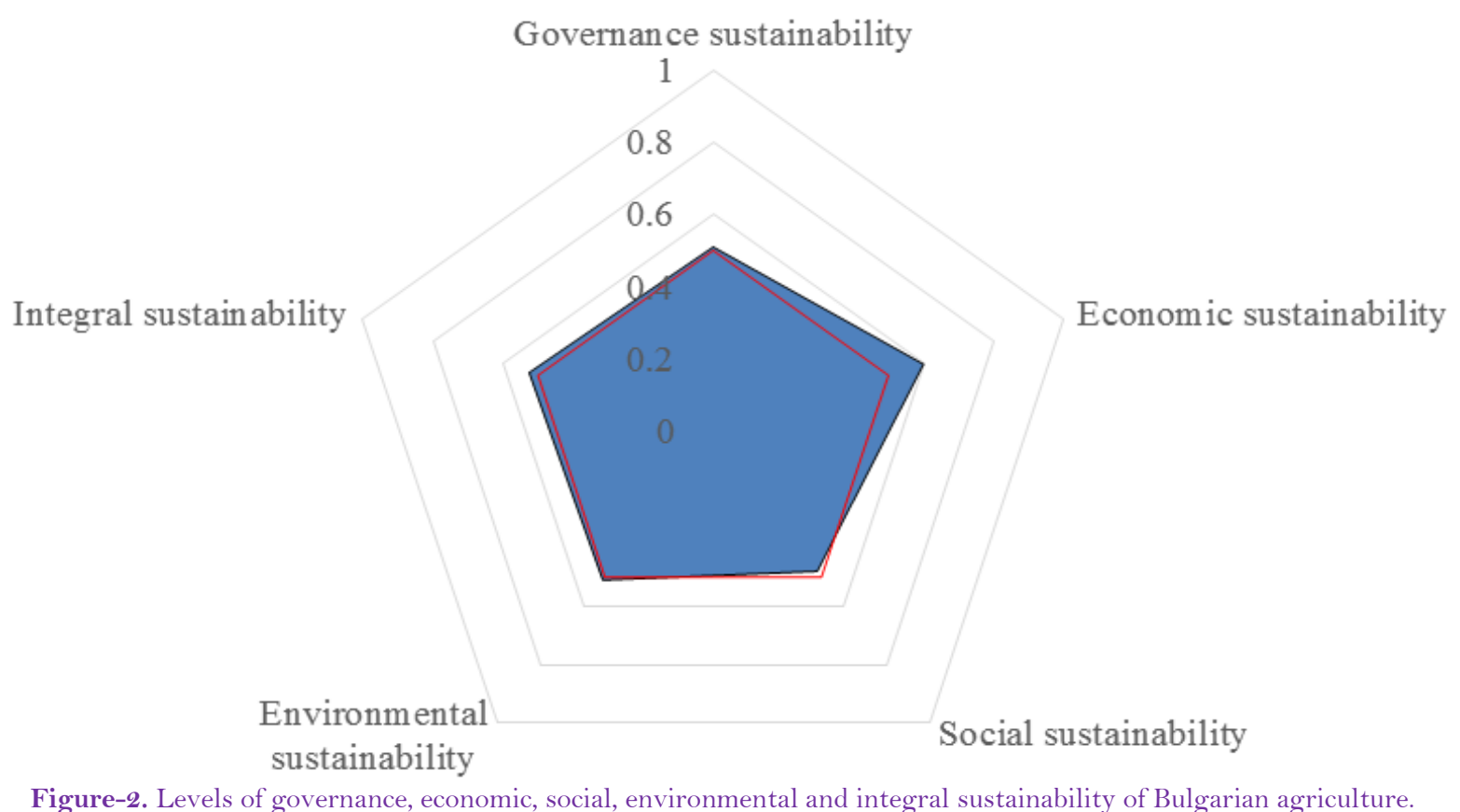

Analysis of individual Indexes for the primary sustainability Principles, Criteria, and Indicators allows identifying individual components contributing to the Governance sustainability of this important sector of Bulgarian economy. For instance, the Governance sustainability of Bulgarian agriculture is relatively low because the Index for the Principle "Good Private Practices" is at "Satisfactory" level $(0,46)$ and compromises the Pillar's Integral sustainability Figure 3. Moreover, Indices for "Good Legislative System" and "Democratic management" are quite low and at the border with the "Satisfactory" level - 0,5 and 0,51 accordingly. At the same time, Indices for the Principles "Working agrarian administration" $(0,55)$ and "Working market environment" $(0,54)$ are highest and contribute most for elevating (ensuring) the Governance Sustainability of the sector.

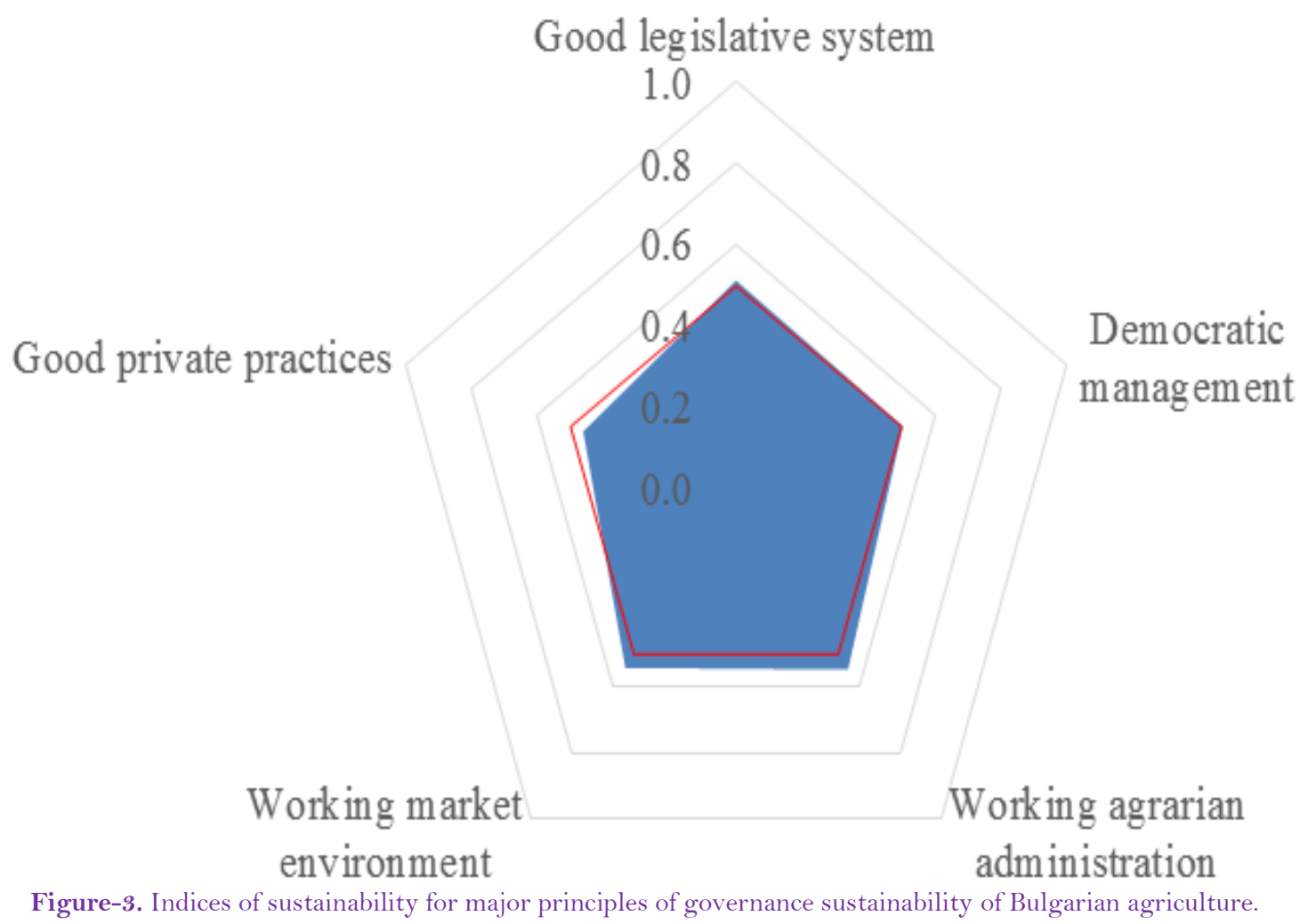

In depth analysis of the levels of the individual Criteria and Indicators further specifies the elements that enhance or reduce country's agricultural Governance sustainability. For instance, the insufficient "Good Private Practices" is determined by the low "External control" (over management) (0,38), weak "Contracts enforcement" $(0,49)$ and inferior "Informal system efficiency" $(0,43)$ Figure 4. Similarly, despite that the Integral Index for "Democratic management" Principle is at a "Good" level, Indices for two criteria (policies) "Impact" and "Stakeholder participation in decision-making") are quite low at satisfactory territory. Likewise, "Working agrarian administration" seems "Good" but "Access to administrative services" is actually very low $(0,34)$ at "Satisfactory" sustainability level. The same is true for the "Working market environment" which is "Good" while Index for the Criteria "Resource concentration" reviles low sustainability $(0,43)$. 


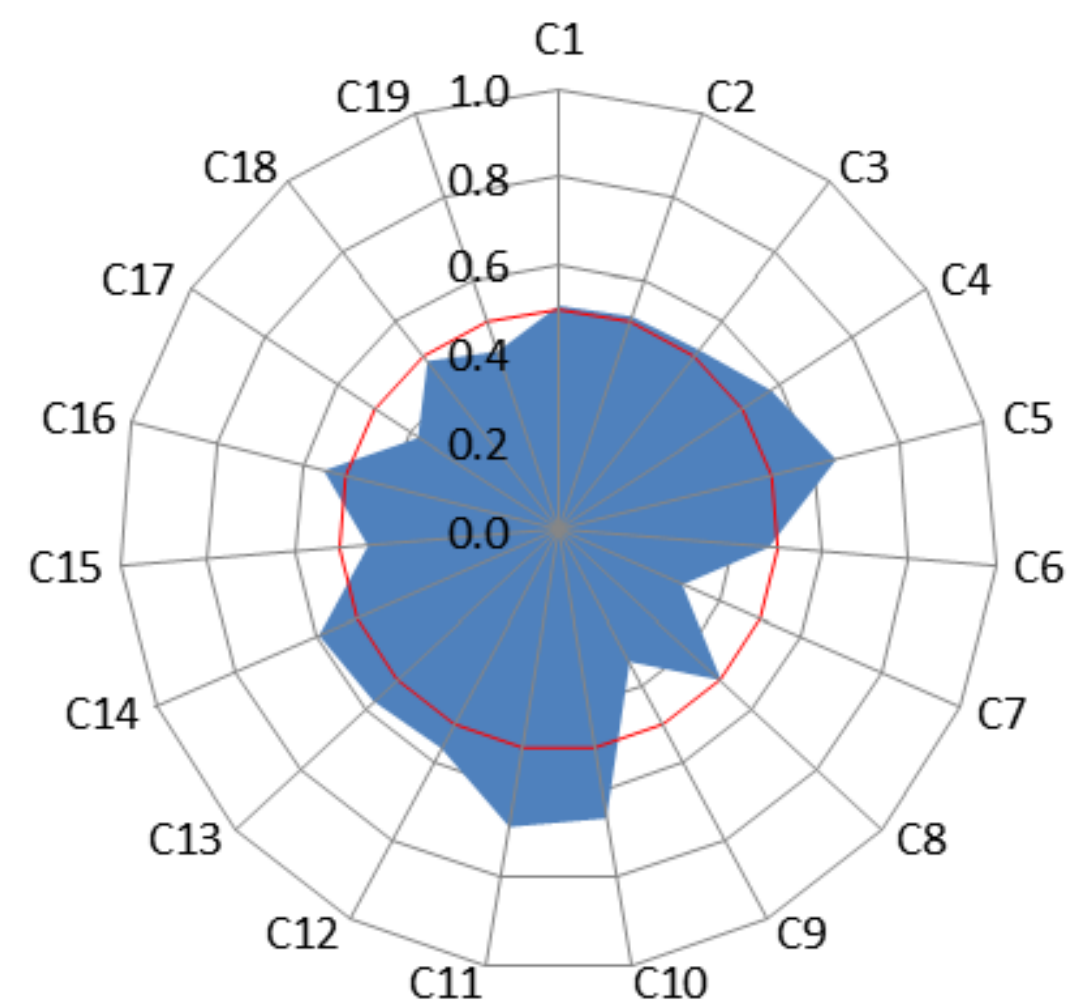

Figure-4. Indices of sustainability for major criteria* of governance sustainability of Bulgarian agriculture.

${ }^{*} \mathrm{C} 1$-Extent of policies implementation; C2-Extent of beneficiary satisfaction of EU policies C3-Policies effects; C4-Representation; C5-Transparency; C6-Impact; C7-Stakeholder participation in decision-making. C8-Minimum costs of using. C9-Access to administrative services; $\mathrm{C} 10-$ Information avalability; $\mathrm{C} 11-\mathrm{Quality}$ of services; $\mathrm{C} 12-\mathrm{M}$ arket acess; $\mathrm{C} 1{ }_{-}$ Frvee, C10Free competition; C14-Competitive allocation of public resources; C15-Resource concentration; C16-Regulation implementation; C17-External control; C18-Contract enforcement; C19-Informal system efficiency.

Individual sustainability Indicators give precise information about the specific factors determining one or another values of a particular Criteria. For example, ineffective "Access to administrative services" is determined accordingly by the insufficient "Agrarian administration efficiency" $(0,31)$ and undeveloped "Administrative services digitalization" $(0,37)$ Figure 5. Likewise "Satisfactory" sustainability for the "Resource concentration" is a consequence of the (low) "Possibility for lands extension" (0,37).

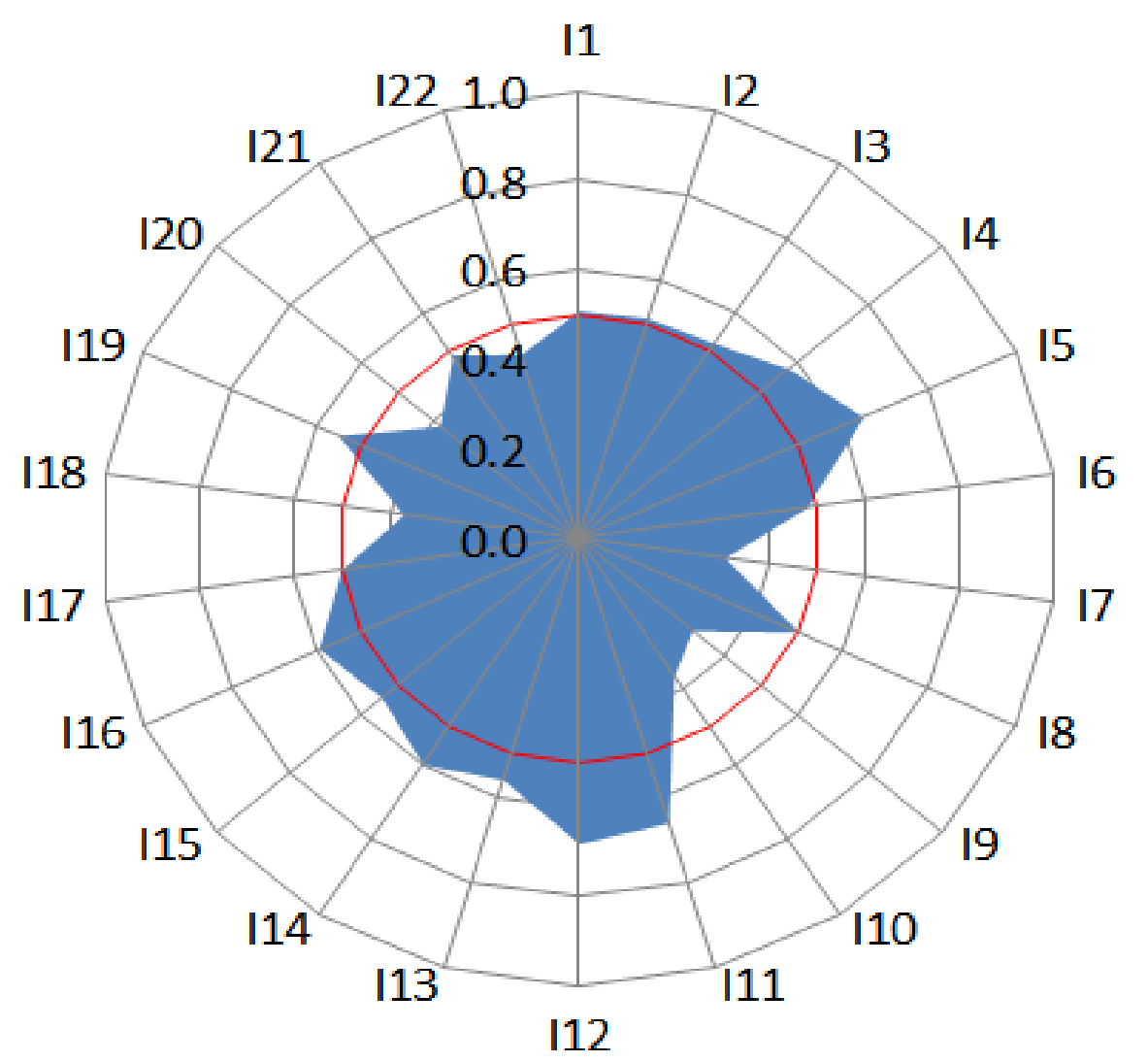

Figure-5. Indicators* for assessing the governance sustainability of Bulgarian agriculture.
* I1-Extent of CAP implementation; I2-Extent of beneficiary satisfaction of EU policies; I3-Subsidies distribution; I4-Representativeness of state and local authorities; I5-Access to information; I6-Subsidies in Income; I7-Farmer's participation in decision-making; I8-Acceptability of legal payments; I9-Agrarian administration efficiency; I10-Administrative services digitalization; I11-Extent of awareness; I12Administration service costs; I13-Market access difficulties; I14-Market competition; I15-Prices negotiation possibilities; I16-Extent of competitive allocation of public resources; I17-Lands concentration; I18Possibility for lands extension; I19-Extent of regulations implementation; I20-Management Board external control; I21-Extent of contract enforcement; I22- Level of informal system efficiency. 
The low values for the Indicators help identify specific areas that require improvement through adequate changes in the institutional environment, public policy, modernization of agrarian administration, collective actions and/or management strategies. At the current stage of the development the most critical for increasing the Governance sustainability of country's agriculture are progressive improvements in following directions: "Farmer's participation in decision-making" (0,31), "Agrarian administration efficiency" (0,31), "Administrative services digitalization" (0,37), "Possibility for lands extension" (0,37), "Management Board external control" (0,38), "Level of informal system efficiency" (0,43), "Subsidies in Income" $(0,48)$, "Extent of contract enforcement" $(0,49)$, "Acceptability of legal payments" (0,5), and "Lands concentration" $(0,5)$.

The higher levels of certain Indicators show the absolute and comparative advantages of the Bulgarian agriculture in terms of good governance and sustainable development. At the current stage of development, the most prominent of these include: "Representativeness of state and local authorities" (0,58), "Market competition" (0.6), "Extent of competitive allocation of public resources" (0.6), "Access to information" (0.65), "Extent of awareness" (0.66), and "Administration service costs" (0.68). Nevertheless, the top value(s) of the Governance sustainability Indicators in Bulgarian agriculture is relatively low. Therefore, there is a great potential for improvement of governance efficiency and further elevate the Governance and Overall sustainability.

The analysis of the Governance sustainability of different sub-sectors of Bulgarian agriculture shows that there is a great variation in the sustainability level. The highest ("Good") level of Governance sustainability is demonstrated in the "Mix livestock" production $(0,59)$, followed by the "Vegetables, flowers, mushrooms" and "Mix crop-livestock" sectors $(0,53)$ Figure 6. Therefore, these three subsectors contribute to greatest extent for improving (maintaining) the overall Governance sustainability of Bulgarian agriculture. On the other hand, the level of Governance sustainability in the "Grazing livestock" $(0,52)$, "Permanent crops" $(0,5)$, and "Beekeeping"

$(0,5)$ is close to the average in the sector. Finally, in some major subsectors like "Field crops" $(0,47)$ and "Mix crops" (0,49), the level of the Governance sustainability is "Satisfactory" and far below the general one. This means that the later subsectors decrease in a biggest degree the Integral Governance sustainability of country's agriculture.

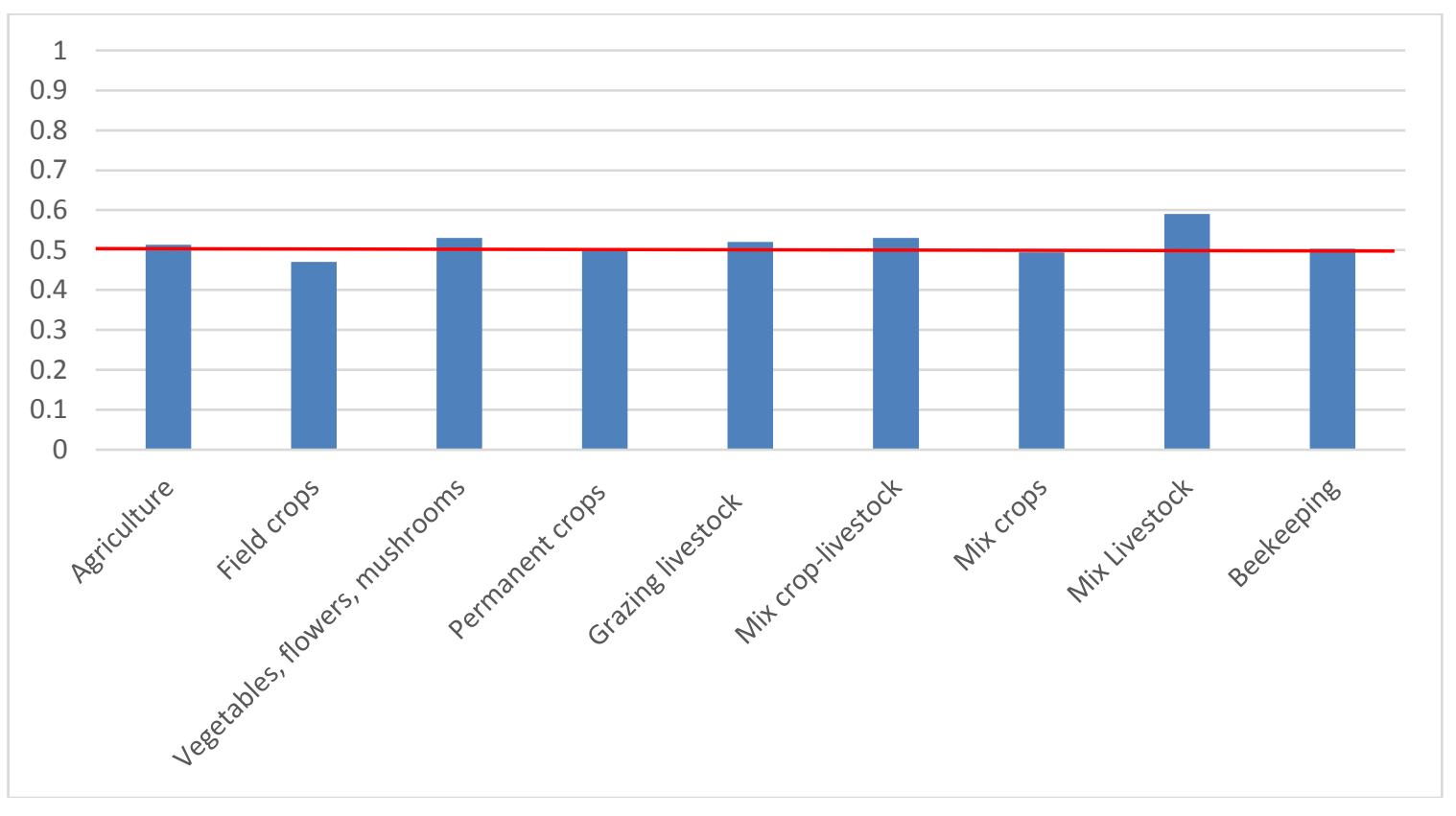

Figure-6. Governance sustainability in different sub-sectors of agriculture in Bulgaria.

The different sub-sectors of Bulgarian agriculture are characterized by significant variation of the levels of Indices of the main Principles of the Governance sustainability Figure 7. For instance, the Principle "Good legislative system" is the best realized in the "Vegetables, flowers, mushrooms" production (0,58) and "Mixlivestock" operations $(0,57)$, and the worst in "Field crops" and "Grazing livestock" sub-sectors (0,47). The Principle of "Democratic management" is the best applied in the "Mix livestock" production $(0,62)$, while it is not "Satisfactory" in the "Beekeeping" (0,46), and "Mix crops" and "Mix crop-livestock" sub-sectors (0,49). The interior and superior levels of the Governance sustainability for particular Principles show the directions for improving the Governance sustainability in the relevant sub-sectors of agriculture.

The Principle "Working agrarian administration" is effectively applied in "Beekeeping" (0,57), and "Grazing livestock" and "Mix crop-livestock" (0,56), while agrarian administration does not "work" well in the sector of "Field crops" $(0,44)$. The sustainability for the Principle "Working market environment" is the highest in "Mix livestock" (0,64), "Beekeeping" (0,63) and "Mix crop-livestock" (0,58). Simultaneously, market mechanisms are not working very well for the "Field crops" producers $(0,5)$. Finally, "Good private practices" are the best implemented in the subsector of "Mix livestock" $(0,62)$ and "Mix crop-livestock" $(0,5)$, while in all other subsectors they are applied only "Satisfactorily", being particularly inferior in the "Beekeeping" (0,37) and "Field crops" (0,41). 


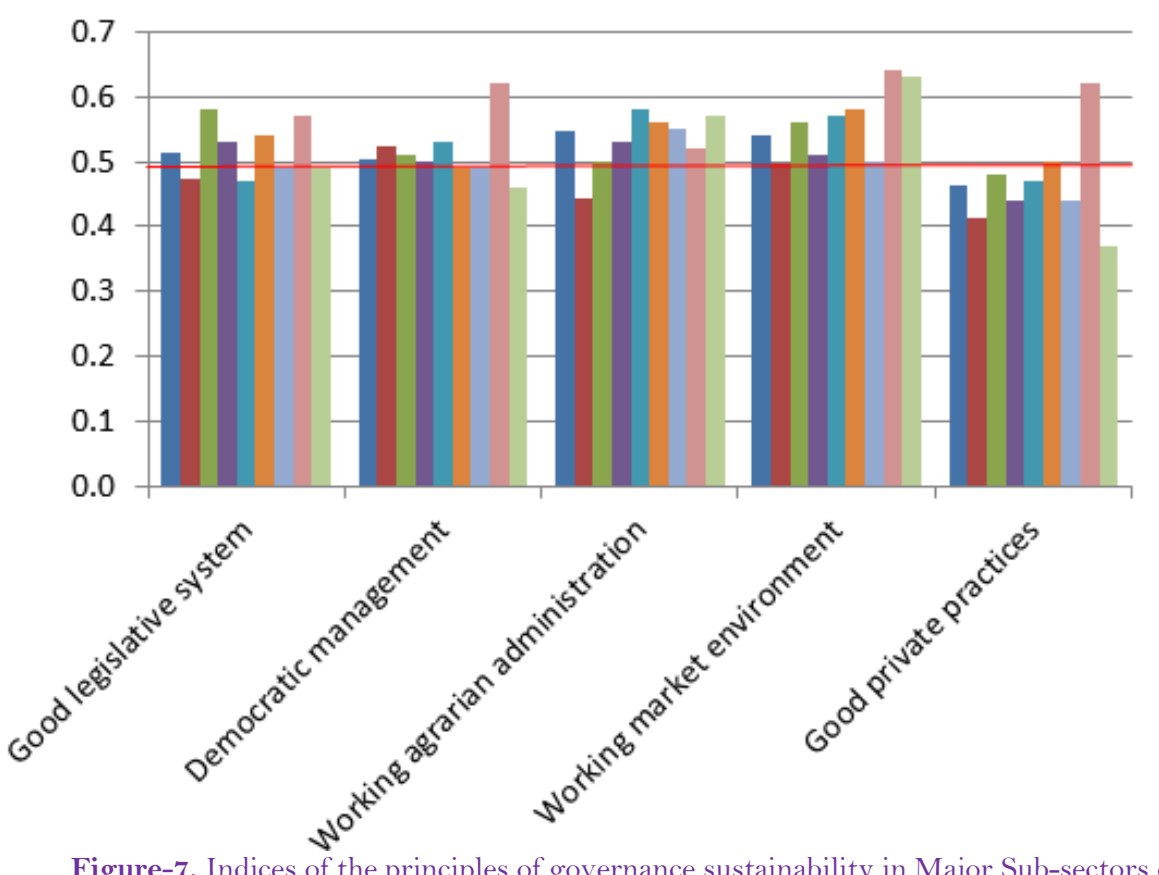

Agriculture

- Field crops

-Vegetables, flowers,

mushrooms

- Permanent crops

- Grazing livestock

घix crop-livestock

Mix crops

Mix livestock

$\square$ Beekeeping

Figure-7. Indices of the principles of governance sustainability in Major Sub-sectors of Bulgarian agriculture.

In depth analysis of that type identifying inferior (critical) levels for sustainability Principles has also a high practical value since they show the specific directions (public, collective and private action areas) for improving the particular (Principle) and the Integral Governance sustainability in the evaluated subsector and agriculture in general.

Further analysis of the sustainability level for the individual Indicators allows "complete" unpacking the "critical" factors enhancing and/or decreasing the Governance sustainability of each sub-sector. Our assessment has found out that different agricultural sub-sectors in Bulgaria are characterized by a significant variation in the levels of individual Governance Sustainability Indicators Figure 8.

Field crops

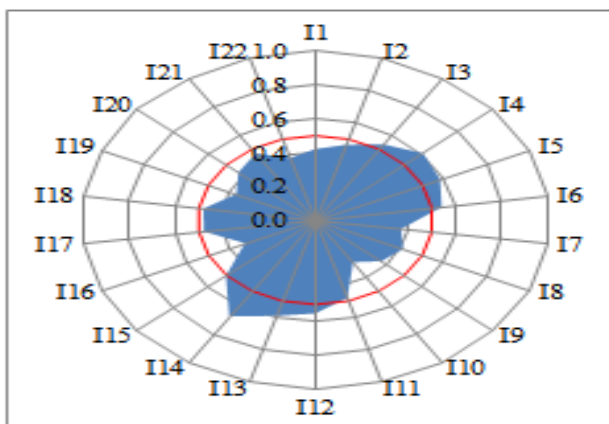

Permanent crops

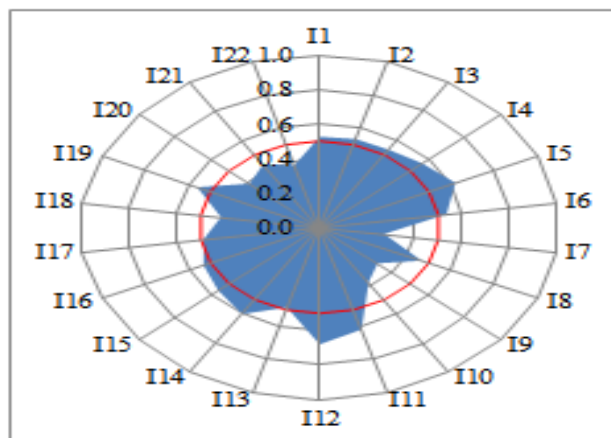

Grazing livestock
Vegetables, flowers and mushrooms

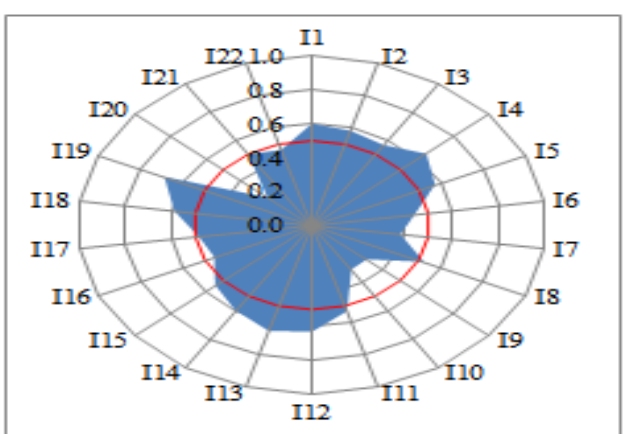

Mixed crops

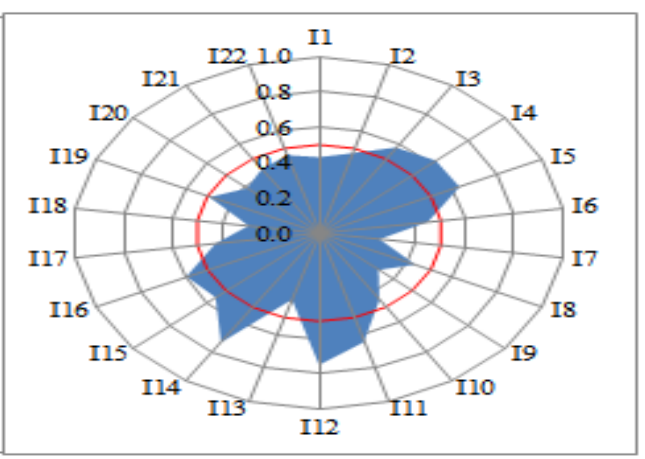

Bee keeping
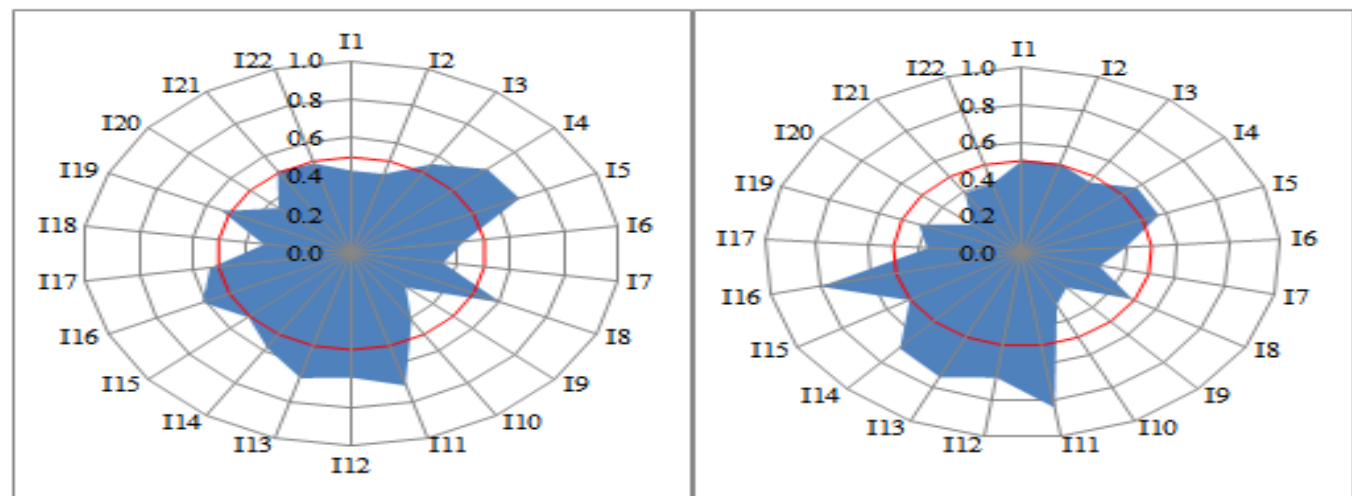


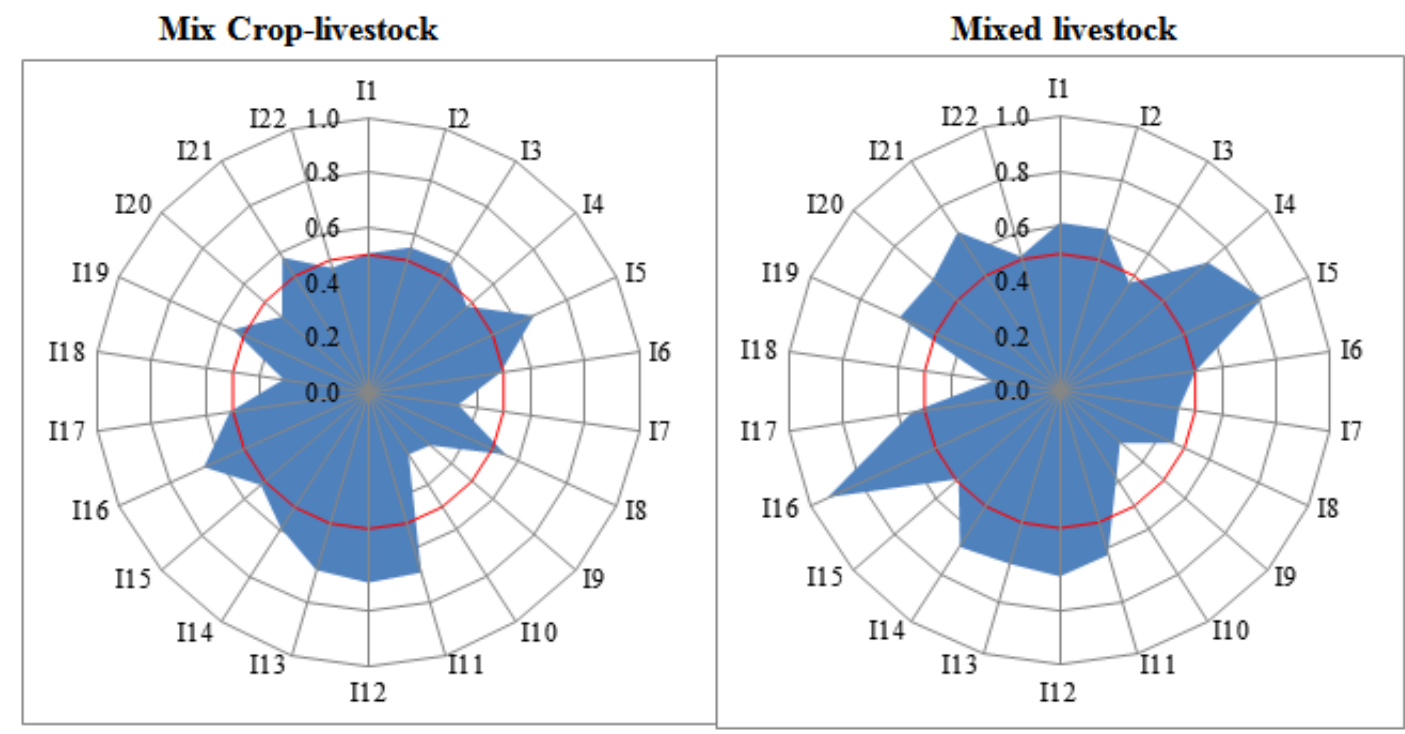

Figure-8. Governance sustainability indicators in different crop sub-sectors of Bulgarian agriculture.

The system of governance of Bulgarian agriculture does not impact equally farms with different juridical type and size of operations. The Governance sustainability of agriculture is the highest for the "Semi-market" ("Mainly subsistence farms") and "cooperative" ("Cooperatives") sectors - the Integral Governance Sustainability Index for these type of farming organizations is much higher than the sectoral average - 0,62 and 0,56 accordingly Figure 9. Other main juridical type of farms like "Physical Persons" and the "Middle size" farming enterprises also have higher than the average Governance Sustainability Index (0,52). Therefore, all these four types of farming organizations contribute to the greatest extent to increasing (maintaining) the "Good" Governance sustainability of Bulgarian agriculture. At the same time, for the "Small size" farms the Governance sustainability is below the national one and at the border with the "Satisfactory" level (0,5). Furthermore, for the "Agro-firms" and "Big size" farming enterprises the Governance sustainability is at "Satisfactory" level - 0.47 and 0.45 accordingly. Consequently, these major type of farming enterprises diminish to the greatest extent the overall Governance sustainability of country's agriculture.

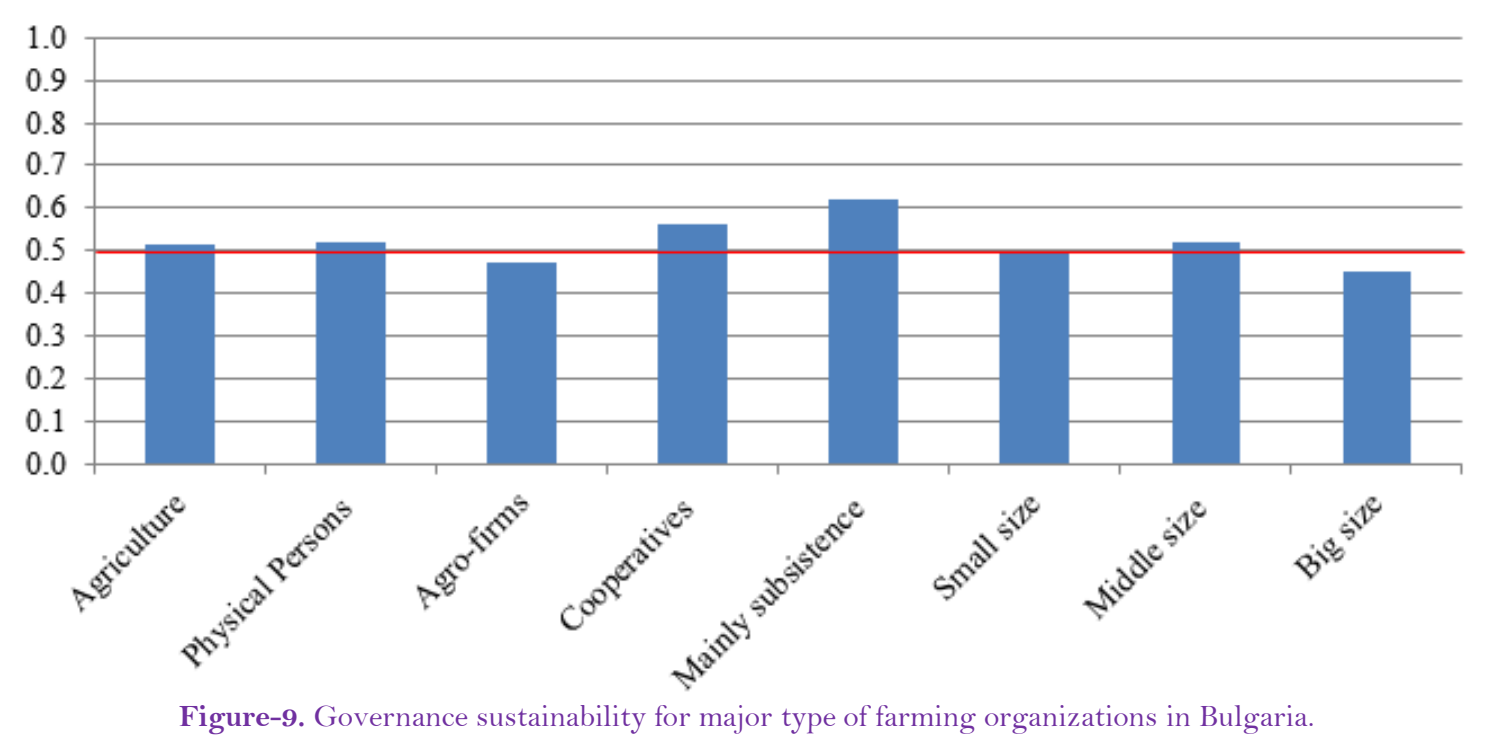

The main Principles of the Governance sustainability are applied ("work") differently in relations to various type of Bulgarian farms. The Governance Sustainability Principles "Good legislative system", "Democratic management" and "Good private practices" the most favorably affect the "Cooperatives" and "Mainly subsistence" farms (Indices of Sustainability accordingly 0,65 and 0,7; 0,55 and 0,67; 0,64 and 0,56) Figure 10. The Governance Sustainability Principle "Working agrarian administration" is the most effectively implemented in regards to "Mainly subsistence" holdings $(0,66)$, "Physical Persons $(0,55)$ and Middle size farms $(0,55)$. The Governance Sustainability Principle "Working market environment" is more favorable for the "Middle size" $(0,57)$ and "Small size" $(0,56)$ farms.

On the other hand, the individual Principles for the Governance sustainability of agriculture are worse applied in and adversely impact different type of farms. The Sustainability for the "Good legislative system" Principle is at "Satisfactory" level for the "Agro-firms" $(0,41)$ and "Small size" farms (0,48). The sustainability Principle "Democratic management" is at "Satisfactory" level only for the "Big size" farming enterprises (0,47). Implementation of the Principle "Working agrarian administration" is inferior ("Satisfactory") for the "Big size" farms $(0,4)$ and "Cooperatives" $(0,43)$; the sustainability Principle "Working market environment" does not work well for the "Big size" farms $(0,38)$ and "Agro-firms" (0,48); and "Good private practices" are not applied sufficiently and badly affect "Agro-firms" (0,43), "Middle size" farms $(0,45)$, "Physical Persons" $(0,46)$, and "Small size" holdings $(0,47)$. 


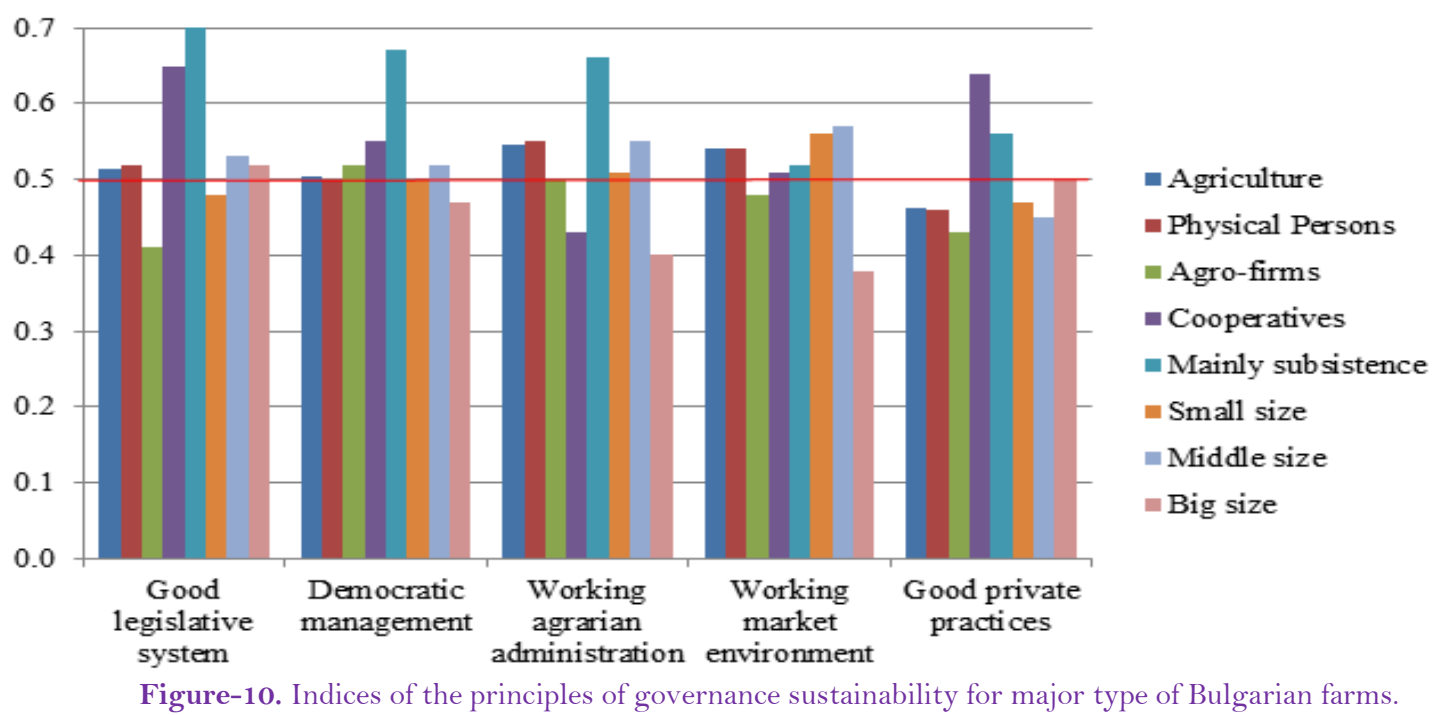

Furthermore, there is significant variation in the level of individual sustainability indicators in farms of different type and size Figure 11.

Physical Persons

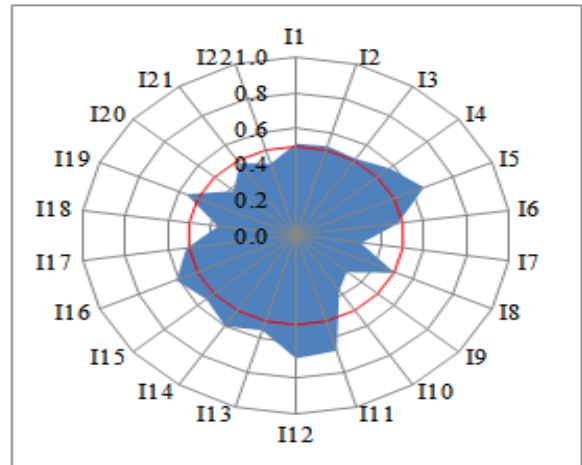

Agro-firms

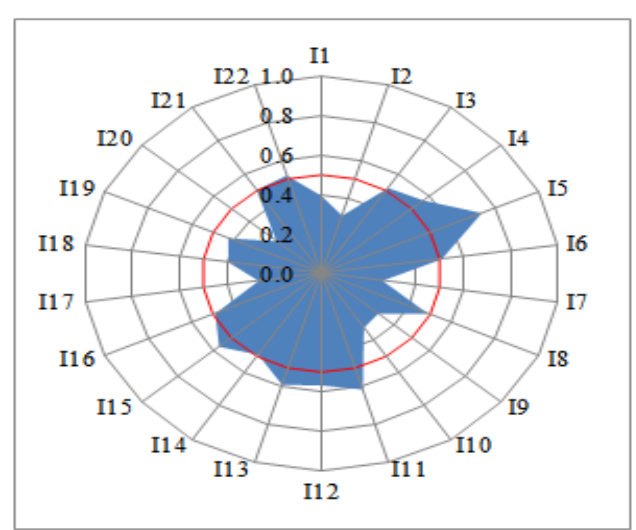

Cooperatives

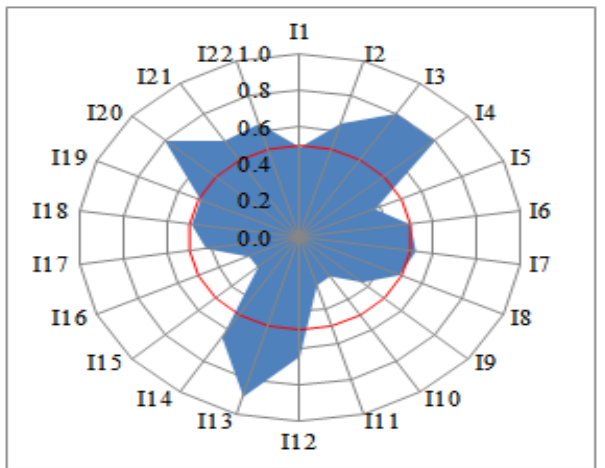

Semi-market farms

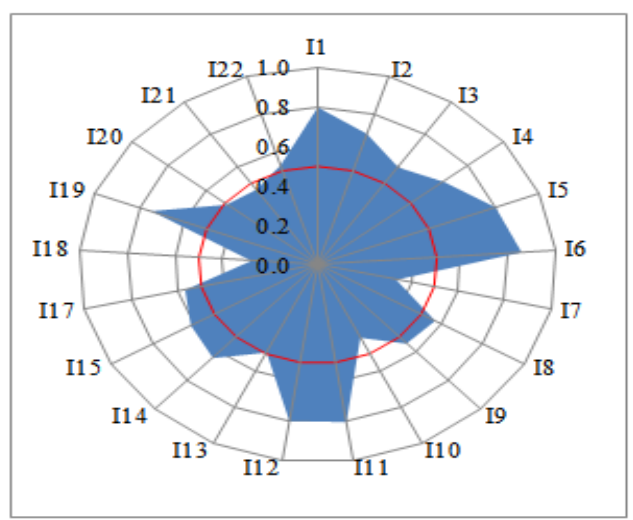

\section{Conclusions}

This first in kind comprehensive assessment of the Governance sustainability of Bulgarian agriculture let make some important specific conclusions about the state of (Governance) sustainability of diverse agro-systems, and recommendations for improvement of the managerial and assessment practices. The elaborated and experimented holistic approach gives a possibility to improve the overall and Governance sustainability assessment. Therefore, it has to be further discussed, experimented, improved and adapted to the specific conditions of evaluated agricultural systems and needs of decision-makers at different levels.

Multiple Principles, Criteria and Indicators assessment of the Governance sustainability of Bulgarian agriculture indicates that the Overall Sustainability is at a "Good" but very close to the "Satisfactory" level. Besides, there is a considerable differentiation in the level of Integral Governance sustainability of different agro-systems in the country - agricultural subsectors, and type of farming organizations. What is more, the individual indicators with the highest and lowest sustainability values determine the "critical" factors enhancing and deterring the particular and integral Governance sustainability of evaluated agro-system.

Having in mind the importance of holistic assessments of this kind for improving the agrarian sustainability in general, and the Governance sustainability of agriculture in particular, they are to be expended and their precision and representation increased. The later requires improvement of the precision through enlargement of surveyed farms and stakeholders, and incorporating more "objective" data from surveys, statistics, expertise of professionals in the area, etc. 
Small Size Farms

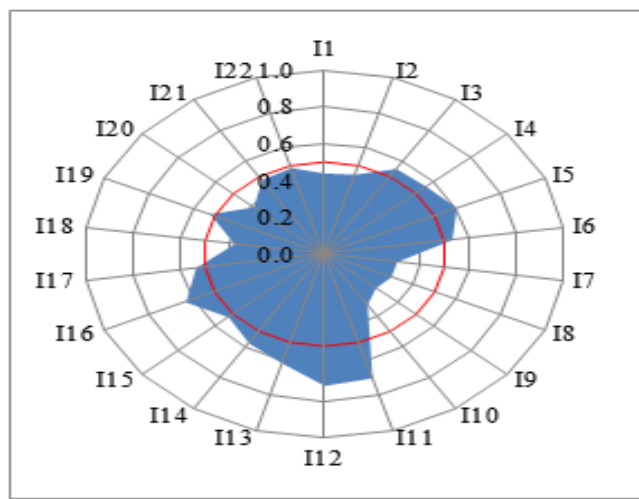

Middle Size Farms

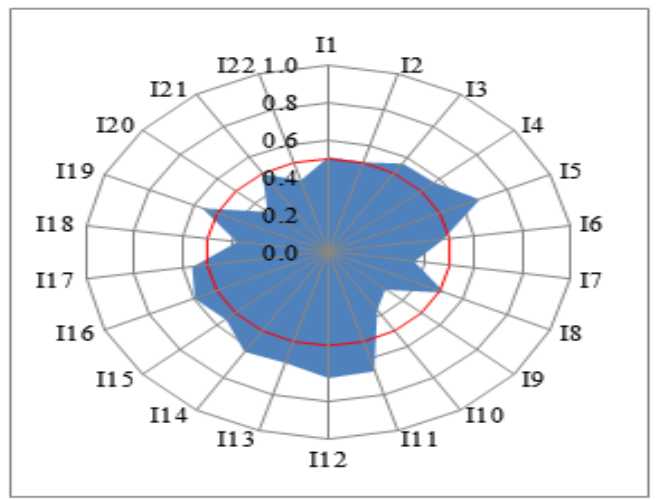

Big Size Farms

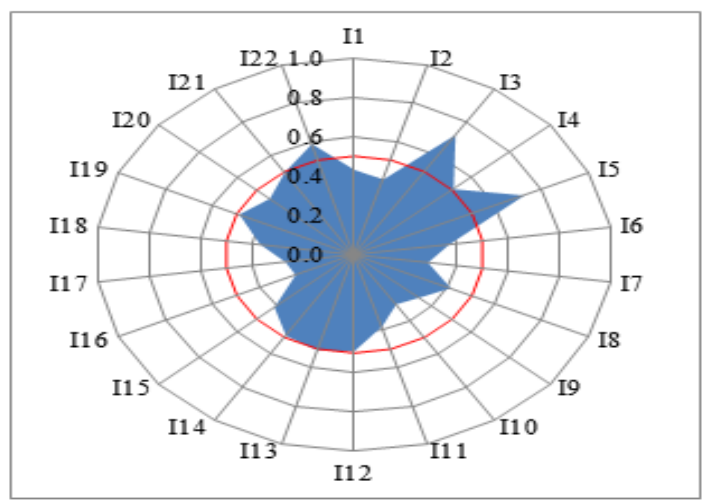

Figure-11. Impact of (contribution to) governance sustainability indicators of major type of farms in Bulgaria.

\section{References}

Altinay, H. (2012). Global governance audit, global economy \& development. Working Paper No. 49, Brookings Institution, Washington, DC.

ASA. (2019). More than green, ASA. Retrieved from: http://www.morethangreen.es/en/ideology/four-sustainabilities-cultural-economicsocial-environmental-sustainability/\#sthash.IjtNJlyH.dpbs.

Bachev, H. (2005). Assessment of sustainability of Bulgarian farms. Paper presented at the Proceedings 11 th Congress of the European Association of Agricultural Economists, Copenhagen.

Bachev, H. (2016). A framework for assessing sustainability of farming enterprises. Journal of Applied Economic Sciences, 11(39), 24-26.

Bachev, H. (2017). Sustainability level of Bulgarian farms. Bulgarian Journal of Agricultural Science, 23(1), 1-13.

Bachev, H. (2018). The sustainability of farming enterprises in Bulgaria: Newcastle upon Tyne: Cambridge Scholars Publishing.

Bachev, H., Ivanov, B., \& Sarov, A. (2020). Unpacking governance sustainability of Bulgarian agriculture. Economic Studies, 6, 106-137.

Bachev, H., Ivanov, B., Toteva, D., \& Sokolova, E. (2016). Agrarian sustainability and its governance-understanding, evaluation, improvement. Journal of Environmental Management ङ Tourism, $7(4(16))$, 639-663.

Bachev, H., Ivanov, B., Toteva, D., \& Sokolova, E. (2017). Agrarian sustainability in Bulgaria - economic, social and ecological aspects. Bulgarian Journal of Agricultural Science, 23(4), 519-525.

Bachev, H., Koteva, N., Kaneva, K., Yovchevska, P., Mitova, D., Ivanov, B., . . Sokolova, E. (2018). Sustainability assessment system for Bulgarian agriculture. Sofia: Institute of Agricultural Economics.

Bachev, H., Koteva, N., Mitova, D., Ivanov, B., Anastasova-Chopeva, M., Toteva, D., \& Mitov, A. (2019). Assessment of sustainability of Bulgarian aghriculture. Sofia: Institute of Agricultural Economics.

Bachev, H., \& Terziev, D. (2017). Environmental sustainability of agricultural farms in Bulgaria. Journal of Environmental Management \& Tourism, 8(5 (21)), 968-994.

Bachev, H., \& Terziev, D. (2018). A study on institutional, market and natural environment impact on Agrarian sustainability in Bulgaria. Journal of Advanced Research in Management, 9(3), 452-478. Available at: https://doi.org/10.14505//jemt.v9.3(27).06.

Bachev, H., \& Terziev, D. (2019). Sustainability of agricultural industries in Bulgaria. Journal of Applied Economic Sciences, 14(1), 118-129.

Bachev, H. (2010). Governance of Agrarian sustainability. New York: Nova Science Publishers.

Bachev, H. (2018). Institutional environment and climate change impacts on sustainability of Bulgarian agriculture. Bulgarian Journal of Agricultural Science, 24(4), 523-536.

Bachev, H. (2017). Socio-economic and environmental sustainability of Bulgarian farms. Agricultural and Resource Economics: International Scientific E-Journal, 3(2), 5-21.

Baeker, G. (2014). Fourth pillar of sustainability, economicdevelopment.org. Retrieved from http://economicdevelopment.org/2014/02/fourth-pillar-of-sustainability-2/. [Accessed February 18, 2014].

Bell, S., \& Morse, S. (2008). Sustainability indicators: Measuring the immeasurable? London: Earthscan.

Bhuta, N., \& Umbach, G. (2014). Global governance by indicators: European University Institute. Retrieved from: http://globalgovernanceprogramme.eui.eu/global-governance-by-indicators/.

Bosselmann, K., Engel, R. \& Taylor, P. (2008). Governance for sustainability - issues, challenges, successes. Gland, Switzerland: IUCN.

City of Brooks. (2019). Municipal sustainability plan, five pillars, city of brooks. Retrieved from https:// www.brooks.ca/211/Sustainability.

CoastalWiki. (2019). Measuring sustainability: The self-assessment of sustainability using indicators and a means of scoring them, Coastal Wiki. Retrieved from http://www.coastalwiki.org/wiki/Measuring_sustainability.

Cruz, J. F., Mena, Y., \& Rodríguez-Estévez, V. (2018). Methodologies for assessing sustainability in farming systems sustainability assessment and reporting: IntechOpen. Retrieved from: https://www.intechopen.com/books/sustainability-assessment-andreporting/methodologies-for-assessing-sustainability-in-farming-systems.

EC. (2001). A framework for indicators for the economic and social dimensions of sustainable agriculture and rural development: European Commission. Retrieved from: http://europa.eu.int/comm/agriculture/publi/reports/sustain/index_en.pdf.

EU. (2019). European Governance, EU. Retrieved from https://eur-lex.europa.eu/summary/glossary/governance.html.

FAO. (2013). SAFA. Sustainability assessment of food and agriculture systems indicators, FAO. Retrieved from: http://www.fao.org/nr/sustainability/sustainability-assessments-safa/en/. 
Fraser, E. D., Dougill, A. J., Mabee, W. E., Reed, M., \& McAlpine, P. (2006). Bottom up and top down: Analysis of participatory processes for sustainability indicator identification as a pathway to community empowerment and sustainable environmental management. Journal of Environmental Management, 78(2), 114-127. Available at: https://doi.org/10.1016/j.jenvman.2005.04.009.

Ganev, G., Popova, M., \& Bönke, F. (2018). Bulgaria report, sustainable governance indicators 2018, SGI 2018, 2 Bertelsmann Stiftung. Retrieved from: https://www.sgi-network.org/docs/2018/basics/SGI2018_Overview.pdf.

Georgiev, M. (2013). Impact of the administration structure and transaction costs on the agricultural land market. Trakia Journal of Sciences, $11(11), 527-534$

Gibson, R. (2006). Beyond the pillars: Sustaibaility assessment as a framework for effective integration of social, economic and ecological considerations in significant decision-making. Journal of Environmental Assessment Policy and Management, 8(3), $259-280$.

Hansen, J. W. (1996). Is agricultural sustainability a useful concept? Agricultural Systems, 50(2), 117-143. Available at: https://doi.org/10.1016/0308-521x(95)00011-s.

Hayati, D., Ranjbar, Z., \& Karami, E. (2010). Measuring agricultural sustainability. In E. Lichtfouse (Ed.), Biodiversity, Biofuels, Agroforestry and Conservation Agriculture, Sustainable Agriculture Reviews 5 (Vol. 5, pp. 73-100): Springer Science.

IFAD. (1999). Good governance: An overview. IFAD, Executive Board - Sixty-Seventh Session, Rome, 8-9 September 1999, EB 99/67/INF. Retrieved from: https://webapps.ifad.org/members/eb/67/docs/EB-67.pdf.

Kamali, F. P., Borges, J. A., Meuwissen, M. P., De Boer, I. J., \& Lansink, A. G. O. (2017). Sustainability assessment of agricultural systems: The validity of expert opinion and robustness of a multi-criteria analysis. Agricultural Systems, 157, 118-128. Available at: https://doi.org/10.1016/j.agsy.2017.07.013.

Kayizari, C. (2018). Good governance as a pillar of sustainable development in Africa, PPP. Retrieved from https://www.aydin.edu.tr/trtr/arastirma/arastirmamerkezleri/afrikam/Documents/Oturum\%203\%20-\%20Good-Governance-as-a-pillar-for-sustainableDevelopment-in-Africa_CaesarKayizari.pdf.

López-Ridaura, S., Masera, O., \& Astier, M. (2002). Evaluating the sustainability of complex socio-environmental systems. The MESMIS framework. Ecological Indicators, 2(1-2), 135-148. Available at: https://doi.org/10.1016/s1470-160x(02)00043-2.

Lowrance, R., Hendrix, P., \& Odum, E. (2015). A hierarchical approach to sustainable agriculture. American Journal of Alternative Agriculture.

Marinov, P. (2019). Index of localization of agricultural holdings and employees in the rural areas of the South Central Region for Bulgaria. Bulgarian Journal of Agricultural Science, 25(3), 464-467.

Monkelbaan, J. (2017). Achieving the sustainable development goals: Theoretical insights and case studies for making sustainability governance more integrative. V. R. F. Series, No. 499, Institute of Developing Economies, Japan External Trade Organization.

Nurse, K. (2006). Culture as the fourth pillar of sustainable development. London, UK: Commonwealth Secretariat.

OECD. (2001). Environmental indicators for agriculture methods and eesults (Vol. 3). Paris: OECD.

RMIT University. (2017). The four pillars of sustainability: RMIT University. Retrieved from: https://www.futurelearn.com/courses/sustainable-business/1/steps/157438.

Sarov, A. (2019). Assessment of the governance sustainability of farms located in mountain areas with natural constraints. Bulgarian Journal of Agricultural Economics and Management, 64(2), 51-59.

Sauvenier, X. S., Valekx, J., Van Cauwenbergh, N., Wauters, E., Bachev, H., Biala, K., \& Peeters, A. (2005). Framework for assessing sustainability levels in Belgium agricultural systems - SAFE. Brussels: Belgium Science Policy.

Scobie, S., \& Young, O. (2018). Integrating governance into the sustainable development goals, Post 2015, UNU-IAS, Policy Brief 3. Retrieved from: https://collections.unu.edu/eserv/UNU:1825/Post2015_UNU-IAS_PolicyBrief3.pdf.

Simberova, I., Kocmanova, A., \& Nemecek, P. (2012). Corporate governance performance measurement-Key performance Indicators. Economics and Management, 17(4), 1585-1593. Available at: https://doi.org/10.5755/jo1.em.17.4.3033.

Singh, R. K., Murty, H. R., Gupta, S. K., \& Dikshit, A. K. (2009). An overview of sustainability assessment methodologies. Ecological Indicators, 9(2), 189-212. Available at: https://doi.org/10.1016/j.ecolind.2008.05.011.

Spangenberg, J. H., Pfahl, S., \& Deller, K. (2002). Towards indicators for institutional sustainability: Lessons from an analysis of Agenda 21. Ecological Indicators, 2(1-2), 61-77. Available at: https://doi.org/10.1016/s 1470-160x(02)00050-x.

Terziev, D., Radeva, D., \& Kazakova, Y. (2018). A new look on agricultural sustainability and food safety: Economic viability. Agrarian and Rural Revitalisation Issues in China and Bulgaria, KSP Books, 231-242. Retrieved from: http://books.ksplibrary.org/978-6052132-57-9-2/.

UCLG. (2014). Culture: Fourth pillar of sustainable development. Barcelona: United Cities and Local Governments.

UN. (2015). The sustainable development goals (SDGs), United Nation. Retrieved from: https://www.un.org/sustainabledevelopment/sustainable-development-goals/.

VanLoon, G., Patil, S., \& Hugar, L. (2005). Agricultural sustainability: Strategies for assessment. London: SAGE Publications.

Citation | Hrabrin Bachev (2020). Measuring the New Governance Pillar of Agrarian Sustainability at Farm, Sectoral and National Level in Bulgaria. Asian Business Research Journal, 5: 28-38.

\section{History:}

Received: 7 July 2020

Revised: 11 August 2020

Accepted: 14 August 2020

Published: 23 September 2020

Licensed: This work is licensed under a Creative Commons

Attribution 3.0 License $(\mathrm{coc})$

Publisher: Eastern Centre of Science and Education
Funding: This study received no specific financial support.

Competing Interests: The author declares that there are no conflicts of interests regarding the publication of this paper.

interests regarding the publication of this paper. Transparency: The author confirms that the manuscript is an honest, accurate, and transparent account of the study was reported; that no vital
features of the study have been omitted; and that any discrepancies from the features of the study have been omit
study as planned have been explained.

Ethical: This study follows all ethical practices during writing.

Eastern Centre of Science and Education is not responsible or answerable for any loss, damage or liability, etc. caused in relation to/arising out of the use of the content. Any queries should be directed to the corresponding author of the article. 